\title{
Semantic Web: A Study on Web Service Composition Approaches
}

\author{
Michael Raj TF \\ Asst. Prof, Dept. of Computer Science, SRC, \\ SASTRA University
}

Siva Prakasam. P

Associate Prof., Dept. of Computer Science, Sri Vasavi College, Erode, Tamil Nadu, India

\begin{abstract}
A Web service is a collection of open protocols and standards used for exchanging data between applications and systems. Web Service discovery, selection and composition are the important tasks of the any automated business processes. In a web service composition set of web services are collectively executed to achieve the objectives. This study reveals the existing approaches used for web service composition in both syntactic and semantic environments. We have reviewed more than 40 articles in this domain and concluded with merits and demerits of the methodologies applied for the implementation of the web service composition.
\end{abstract}

\section{KEYWORDS}

Service oriented architecture, Web service composition, Semantic web, Semantic service discovery

\section{INTRODUCTION}

Web service is a component can be remotely identified by the URL and they are heterogeneous in nature [1]. These components are described and accessed by using the various standards XML, SOAP, WSDL and UDDI [2]. Web services are constructed based on the Service Oriented Architecture (SOA), which is depicted in the figure 1 and are distributed across the web to service numerous business applications. Implementation of business applications with the help of web services includes various operations such as service request, request preprocessing, service matching, service discovery, service selection, service composition.

These operations can be done in many ways and various methodologies and approaches have been developed and employed. Considering and selecting those approaches for the specific environment is a tedious task because numbers of services are keep on increasing over the year. This article aims to simplify the searching process for the appropriate methodologies for the designated web service composition. We have surveyed more than 40 research articles and are listed with merits and demerits of it.

A web service composition problem can have six dimensions such as composition language, knowledge reuse, automation, tool support, execution platform, target users. It is also determining the work flow for an automated process [3]. The selection of the approaches was a three-step process that involved preliminary selection, further selection, refinement.

The general framework of a web service composition has different components, one of them is process generator based on the external and internal specification of a service of a service consumer and service provider respectively. There are 12 platforms: eFlow, FormSys, Intalio BPMS, Self-Serv, SHOP2, Sword, Taverna, XL, Yahoo!Pipes, YAWL, jBPM, JOpera [8].

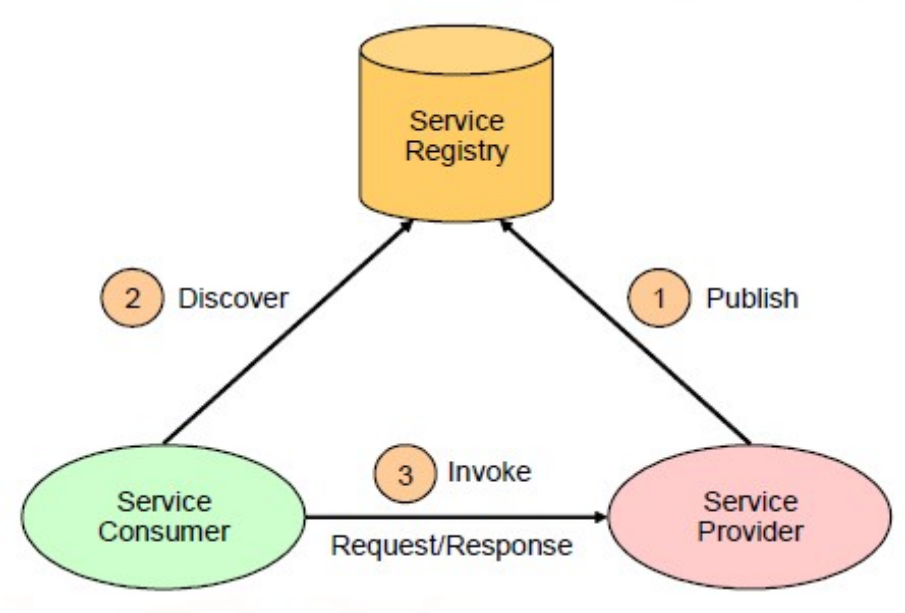

Fig 1. Components of SOA

Integration of web services into composite services or applications, which is a highly sensible and conceptually non-trivial task and is recognized in both 
the enterprise and the consumer areas [10] [13][20]. The criteria based web service selection methods are mostly used to achieve the objectives of domain, which can be classified as follows [14]

- $\quad$ service-ranking approach

- linear programming method

- fuzzy model

- QoS-based service selection method

- hybrid models

- ANP

The entire article is organized as follows Section-I contains the introductory concepts. Section-II give the overview of the various approaches, merits and demerits of them and Section-III concludes article with the observations of the review.

\section{OVERVIEW}

Web service integration is an important task of any automation of business process. Web Service Discovery is the process of finding a suitable web service for a given task. The life cycle for semantic web services composition includes technologies used for composition approaches, modeling and service management [32]. Web Service Composition is the process of integrating related web services, is to provide set of composite services. Web service searching, selection and composition can be done in two ways: a) syntactic b) semantic [31]

The various approaches for dynamic web service composition have been discussed. To meet the user's requirements regarding on-demand delivery of customized services, dynamic web service composition approaches have emerged. In a dynamic environment, realizing dynamic web service composition is not so easy. The evaluation shows that transactional support is still missing. The verification of the compositional correctness is also missing SelfHealing Web Service Compositions [43].

This literature survey about web service composition, discovery and selection shows evaluation in the service oriented architecture domain. The following Table 1 lists the methodologies, outcome, merits and demerits of those approaches. The primary task of any web service composition can be started with service discovery. The semantic based discovery model is explained in [33].
Petri Net based approach, which focuses on the reliability calculation method. It uses Fuzzy Reasoning Colored Petri Net (FRCPN), ServiceOriented Architecture (SOA), Supercomputing Cloud Platform (SCP); Sequential Linked List for Filling Reliability Value (SLLFRV), Ontology, Web language for Services (OWL-S), a method called $\mathrm{T}$ is proposed to quantify the reliability of a repairable system [4].

Non-deterministic planning methods for automated web service composition is explained in [5]. Performance of a web service composition can be improved by minimizing the response time of web service composition. QoS Properties Response Time, Execution Time, Reputation, Availability, Accessibility, Throughput and Scalability [6].Consideration of e-government services and its service composition is discussed with semantic features. It encompasses information and communications technologies (ICT) with customercentric approach. It is a Semantic Web (SW) enabled Multi-Agent System (MAS), Autonomic Computing especially self-healing propriety, Artificial Intelligent Planning (AIP), ontoGov (Ontology-enabled e-Gov Service Configuration), WebDG, eGOIA (Electronic Government, Innovation and Access) eMayer [7].

Dynamic Web Services Composition uses QoS parameters with the utilization of genetic algorithm is described in [9] and gives optimized results. [11] Proposed an approach to compose the web service based on the trustworthiness of it. From the basic observation a graph is formed which denotes the web service participated in the service composition. The basic notions used for representing the graph is such as Petri nets, oWF-nets, Labeled Transition Systems and Opacity of a Labeled Transition System [12]. Criteria based service selection methods were introduced and approach considers various parameters such as Quality of service, User Preference and Scalability [14].

Semantic web service discovery has so many challenges in-terms of technologies to be used such as OWL-S, WSMO,WSML,WSMX,SAWSDL and the tasks needs to be carried out by the discovery process such as publishing, mediation, storage, request, matchmaking, negotiation and selection [17][27][31] [35]. 
The privacy data are distributed across the web for example medical data. These data are to be shared by means of web services and its composition. This type of composition is disused in [15]. The level of privacy is determined by the rules defined in the composition architecture. Clustering Web services is very much important to facilitate service discovery. It can be done in many ways, one of them is based on the parameters used in the web service invocation [16].QOS-based web service composition based on Genetic Algorithm (GA) is introduced in [18][21]. This GA based approach is considering QoS parameters. Business Process Execution Language (BPEL) based composition uses behavioral approach by verifying the concurrent properties [19].

Web service composition process can employ either manual or semi-automatic or automatic methodologies. Automatic web service composition is used when dynamic composition is required [22]. Firefly approach is the which provides optimal solutions for dynamic service composition[23] and another web service composition framework provides the solution for the composition problems on the fly that is dynamically called User-Centric WS-Mediator framework for on-the-fly Web Service Composition [24] [26].

An Optimization Method of Workflow-based Web Service Composition Model is a computational model, calculates QoS and then formulates the composition [25].The researchers, software developers, advanced practitioners, documentation writers, and users involved in Web services domain for QOS predictions exploring development opportunities especially in web databases.

Log-based mining techniques are used to identify the patterns of the web service access and composition. It's a reengineering approach for service composition and another easy web service discovery approach is a query-by-example approach [28] [29]. Well defined business process can employ the goal-based approach for Web service composition [34]. A linear approach for web service composition uses QoS parameters and provides transactional aware results [36] and context aware solution is useful for domain specific problem and yields better results [34].

A theorem proving framework for the formal verification of web services composition has explained and the methodologies can be used in post composition[38] [39].Optimization and Ranking in web service composition using Performance Index (PI) [42]. Huge number of services in the repository increases the processing time for selection, discovery and composition. The performance of the composition framework can be reduced by means of parallel processing [44].

A number of web services have been carried out on cloud computing, including performance analysis, market-oriented graph Semantic Web Services, management tool, workload balance, dynamic selection, etc. semantic $\mathrm{I} / \mathrm{O}$ information of the services. presenting the nonfunctional characteristics of the software systems and services.

QoS of cloud services can be measured from either the client side (e.g., response time, throughput, etc.) or at the server side (e.g., price, availability, etc.).

\section{A. QOS Perspective}

Quality-of-service can be measured either at the server side or at the client side. Client-side QoS properties provide more accurate measurements of the user usage experience. The commonly used clientside QoS properties include response time, throughput, failure probability, etc. This paper mainly focuses on ranking prediction of client-side QoS properties, which likely have different values for different users (or user applications) of the same cloud service.

Definition and Execution of Composite Web Services The SELF-SERV Project [40] The SELF-SERV project aims at providing tool support and middleware infrastructure for the definition and execution of composite Web services. SELF_SERV system: key aspects, Declarative service composition the number of services to be composed may be large and continually evolving highly distributed nature of services. In SELF-SERV, the process model is specified as a state chart, states and invocations to Web services transitions events, conditions, and variable assignment operations.

SELF-SERV exploits the concept of service community. Prototype system in which Web services are declaratively composed and the resulting composite services can be orchestrated either in a 
peer-to-peer or in a centralized way within a dynamic environment. SELF-SERV is an ongoing research project that aims at providing tool support and middleware infrastructure for facilitating the composition of Web services in large, autonomous, heterogeneous, and dynamic environments. Several obstacles still hinder the seamless provisioning of Web services in mobile environments. Examples of such obstacles are:
- throughput

- connectivity of wireless networks,

- limited computing resources of mobile devices

- risks of communication channel

- disconnections

The SELF-SERV architecture to support service provisioning in mobile environments. The issues are,

Context-sensitive service selection and

$>$ Handling disconnections during composite service execution

TABLE 1 Web service composition methodologies

\begin{tabular}{|c|c|c|c|c|}
\hline S.No & Approach/Methodology & Outcome & Features & Limitations \\
\hline 1. & Fuzzy approach [4] & $\begin{array}{l}\text { Composition } \\
\text { is returned as } \\
\text { SLLFRV } \\
\text { linked list } \\
\text { with the } \\
\text { reliability } \\
\text { value of } \\
\text { FRCPN }\end{array}$ & $\begin{array}{l}\text { Reliability of the } \\
\text { Web service } \\
\text { composition has a } \\
\text { correlation with } \\
\text { the number of web } \\
\text { services and the } \\
\text { range of reliability } \\
\text { transition values. }\end{array}$ & $\begin{array}{l}\text { If the FRCPN } \\
\text { values of the } \\
\text { reliability range of } \\
\text { transitions is } \\
\text { smaller, then the } \\
\text { reliability value of } \\
\text { FRCPN is smaller. }\end{array}$ \\
\hline 2. & $\begin{array}{l}\text { Non-Deterministic planning } \\
\text { methods: } \\
\text { 1) Background } \\
\text { 2) Probabilistic planning } \\
\text { 3) Determination methods } \\
\text { 4) Planning in the belief state } \\
\text { space } \\
\text { 5) Translation methods } \\
\text { Web service composition methods: } \\
\text { 1) Deterministic methods } \\
\text { 2) Middle ground methods } \\
\text { 3) Non-deterministic } \\
\text { contingent planning methods } \\
\text { [5] }\end{array}$ & $\begin{array}{l}\text { Deterministic } \\
\text { method } \\
\text { generates all } \\
\text { feasible } \\
\text { solution based } \\
\text { on service } \\
\text { graph. }\end{array}$ & $\begin{array}{l}\text { Fully automatic } \\
\text { and Graph based } \\
\text { composition }\end{array}$ & $\begin{array}{l}\text { In a stochastic } \\
\text { environment, output } \\
\text { is not predictable. } \\
\text { Outcome of the } \\
\text { execution of n web } \\
\text { service cannot } \\
\text { always be } \\
\text { anticipated. }\end{array}$ \\
\hline 3. & QoS Normalization [6] & $\begin{array}{l}\text { Based on QoS } \\
\text { properties }\end{array}$ & $\begin{array}{l}\text { QoS score and user } \\
\text { requirements. } \\
\text { Optimized } \\
\text { response time. }\end{array}$ & $\begin{array}{l}\text { Web service } \\
\text { selection and } \\
\text { discovery system is } \\
\text { essential to provide } \\
\text { clients with proper } \\
\text { results according to } \\
\text { their requirements. } \\
\text { It is impossible to } \\
\text { fulfill this task } \\
\text { without considering } \\
\text { the ranking relation }\end{array}$ \\
\hline
\end{tabular}


www.ijtsrd.com

\begin{tabular}{|c|c|c|c|c|}
\hline & & & & $\begin{array}{l}\text { between thousands } \\
\text { of available } \\
\text { candidates with } \\
\text { similar } \\
\text { functionalities }\end{array}$ \\
\hline 4. & $\begin{array}{l}\text { customer-centric approach, Multi- } \\
\text { Agent System (MAS) [7] }\end{array}$ & $\begin{array}{l}\text { Dynamic way } \\
\text { to provide a } \\
\text { personalized } \\
\text { service that } \\
\text { improves the } \\
\text { satisfaction } \\
\text { of the citizen } \\
\text { andthus } \\
\text { increase the } \\
\text { quality of } \\
\text { publicservices. }\end{array}$ & $\begin{array}{l}\text { e-GovernmentWeb } \\
\text { services, enabling } \\
\text { citizens to } \\
\text { dynamically } \\
\text { compose services } \\
\text { according to their } \\
\text { goals andthrough a } \\
\text { single point of } \\
\text { access. } \\
\text { Its faster, cheaper, } \\
\text { more } \\
\text { personalized and } \\
\text { more efficient } \\
\text { delivery services }\end{array}$ & \\
\hline 5. & $\begin{array}{l}\text { QoS Parameters and Genetic } \\
\text { Algorithm(GA) [9] }\end{array}$ & $\begin{array}{l}\text { Optimal } \\
\text { composition. }\end{array}$ & $\begin{array}{l}\text { Dynamic web } \\
\text { services } \\
\text { composition use of } \\
\text { QoS parameters } \\
\text { and GA. }\end{array}$ & \\
\hline 6. & $\begin{array}{l}\text { Diversified Service Rank (DSR). } \\
\text { Web service reputation } \\
\text { apdate } \\
\text { algorithm. Reputation } \\
\text { discovery approach [11] }\end{array}$ & $\begin{array}{ll}\text { Returns } & \text { the } \\
\text { matching } & \text { list } \\
\text { of } & \\
\text { services. } & \end{array}$ & $\begin{array}{l}\text { Consumer } \\
\text { provides more } \\
\text { accurate values of } \\
\text { reputation. } \\
\text { Returned list of } \\
\text { nominated web } \\
\text { service is the most } \\
\text { relevant to the } \\
\text { consumer request. }\end{array}$ & \\
\hline 7. & $\begin{array}{l}\text { Symbolic Observation Graphs } \\
\text { (SOGs)-verification of their } \\
\text { individual abstractions [12]. }\end{array}$ & $\begin{array}{l}\text { Abstract and } \\
\text { check the } \\
\text { opacity } \\
\text { of Web } \\
\text { services and } \\
\text { their } \\
\text { composition, } \\
\text { and therefore } \\
\text { prove } \\
\text { their }\end{array}$ & $\begin{array}{l}\text { Privacy, through } \\
\text { the use of } \\
\text { Symbolic } \\
\text { Observation } \\
\text { Graphs. }\end{array}$ & $\begin{array}{lr}\text { Information leakage, } \\
\text { hiding }\end{array}$ \\
\hline 8 & $\begin{array}{l}\text { Criteria based service } \text { selection } \\
\text { methods [14]. }\end{array}$ & $\begin{array}{l}\text { Determines } \\
\text { the weights of } \\
\text { criteria based } \\
\text { on user } \\
\text { preference } \\
\text { and accounts } \\
\text { for the } \\
\text { confidence }\end{array}$ & More efficient & $\begin{array}{l}\text { The behavior of } \\
\text { QoS-based } \\
\text { service selection } \\
\text { leads to service } \\
\text { selection problems } \\
\text { in Multi-Criteria } \\
\text { Decision Making } \\
(\mathrm{MCDM}) \text {. }\end{array}$ \\
\hline
\end{tabular}


www.ijtsrd.com

\begin{tabular}{|c|c|c|c|c|}
\hline & & $\begin{array}{l}\text { level of } \\
\text { decision } \\
\text { makers. }\end{array}$ & & \\
\hline 9 & $\begin{array}{l}\text { Privacy based } \\
\text { 1) Privacy Level } \\
\text { 2) Privacy Rule } \\
\text { 3) Privacy Policy } \\
\text { Mechanism: } \\
\text { Negotiation } \\
\text { Approaches:Privacy Preserving } \\
\text { DaaS composition [15]. }\end{array}$ & & $\begin{array}{l}\text { Data as a Service } \\
\text { (DaaS) builds on } \\
\text { service-oriented } \\
\text { technologies to } \\
\text { enable fast access } \\
\text { to data resources } \\
\text { on the Web. } \\
\text { DaaS composition } \\
\text { may reveal } \\
\text { privacy-sensitive } \\
\text { information. } \\
\text { The privacy model } \\
\text { allows a service } \\
\text { todefine a privacy } \\
\text { policy and a set of } \\
\text { privacy } \\
\text { requirements. }\end{array}$ & $\begin{array}{l}\text { Two factors } \\
\text { exacerbate the } \\
\text { problem of privacy } \\
\text { in DaaS. } \\
\text { 1) DaaS services } \\
\text { collect and store } \\
\text { a } \\
\text { large amount of } \\
\text { private information } \\
\text { about users. } \\
\text { 2) DaaS services are } \\
\text { able to share } \\
\text { thisinformation } \\
\text { withother entities. }\end{array}$ \\
\hline 10 & $\begin{array}{l}\text { Hybrid Web } \\
\text { tagrecommendation strategy, named } \\
\text { WSTRec } \\
\text { Normalized } \\
\text { Distance(NGD)-to compute the } \\
\text { content-level similarity between } 2 \\
\text { web services [16]. }\end{array}$ & $\begin{array}{l}\text { Utilize tagging } \\
\text { data to } \\
\text { improve the } \\
\text { performance } \\
\text { of traditional } \\
\text { WSDL } \\
\text { document- } \\
\text { basedWeb } \\
\text { service } \\
\text { clustering for } \\
\text { the purpose } \\
\text { ofmore } \\
\text { accurateWeb } \\
\text { service } \\
\text { discovery. }\end{array}$ & $\begin{array}{l}92 \% \text { ofWeb } \\
\text { services cached by } \\
\text { Web service search } \\
\text { engines are valid } \\
\text { and active. } \\
\text { Web services } \\
\text { search engine } \\
\text { Seekda!1 allows } \\
\text { users to manually } \\
\text { associater tags } \\
\text { withWeb services. }\end{array}$ & $\begin{array}{l}\text { More than } 53 \% \text { of } \\
\text { registered services } \\
\text { in } \\
\text { businessregistries } \\
\text { are } \\
\text { invalid. }\end{array}$ \\
\hline 11. & $\begin{array}{l}\text { QoS approach.GA based algorithm } \\
\text { has } 2 \text { constraints: } \\
\text { 1) only one web service among } \\
\text { candidate web services } \\
\text { should be chosen for a task } \\
\text { 2) the service composition } \\
\text { must satisfy user constraints } \\
\text { [18]. }\end{array}$ & $\begin{array}{l}\text { GA, plan } \\
\text { optimizer with } \\
\text { constraints }\end{array}$ & $\begin{array}{l}\text { It overcome local } \\
\text { optimums with } \\
\text { less computation } \\
\text { time. } \\
\mathrm{GA} \text { is a } \mathrm{K} \text { beam } \\
\text { search; it can find } \\
\text { suitable } \\
\text { composition plan } \\
\text { much faster than } \\
\text { other random } \\
\text { search approaches. }\end{array}$ & \\
\hline
\end{tabular}


www.ijtsrd.com

\begin{tabular}{|c|c|c|c|c|}
\hline 12. & $\begin{array}{l}\text { Extended control flowgraph } \\
\text { (XCFG). WS-BPEL Two main } \\
\text { tasks: } \\
\text { 1) XCFG construction } \\
\text { 2) property verification. } \\
\text { XCFGV4BPEL: a tool for verifying } \\
\text { concurrent properties } \\
\text { 1) Automata Based Techniques } \\
\text { 2) Process Algebra Based } \\
\text { Techniques } \\
\text { 3) Petri Net Based Techniques } \\
\text { [19] }\end{array}$ & $\begin{array}{l}\text { Verifies } \\
\text { concurrent } \\
\text { behavior in } \\
\text { BPEL. }\end{array}$ & $\begin{array}{l}\text { XCFG can model } \\
\text { not only the } \\
\text { workflow ofBPEL } \\
\text { but also the } \\
\text { synchronization } \\
\text { control } \\
\text { dependencies } \\
\text { amongconcurrent } \\
\text { activities. } \\
\text { XCFG } \\
\text { Advantages: } \\
\text { 1) XCFG } \\
\quad \text { supports } \\
\quad \text { concurrent } \\
\text { control } \\
\text { flow compared } \\
\text { with traditional } \\
\text { CFG } \\
\text { 2) XCFG } \\
\text { model can } \\
\text { link } \\
\text { indicates } \\
\text { synchronization } \\
\text { dependency } \\
\text { between } \\
\text { concurrent } \\
\text { activities } \\
\text { 3) field in XCFG } \\
\text { is introduced to } \\
\text { recordthe } \\
\text { information } \\
\text { related elements } \\
\text { for the purpose of } \\
\text { analysis } \\
\text { verification. and } \\
\text { and }\end{array}$ & \\
\hline 13. & $\begin{array}{l}\text { Hybrid firefly method for selecting } \\
\text { the optimal solution in } \\
\text { semanticWeb service composition } \\
{[23] \text {. }}\end{array}$ & $\begin{array}{l}\text { Firefly- } \\
\text { inspired } \\
\text { method for } \\
\text { selecting the } \\
\text { optimal or a } \\
\text { near optimal } \\
\text { solution in } \\
\text { semantic Web } \\
\text { service } \\
\text { composition. }\end{array}$ & $\begin{array}{l}\text { Biological systems } \\
\text { have led to the } \\
\text { design of efficient } \\
\text { techniques that can } \\
\text { be used to solve } \\
\text { optimization } \\
\text { problems. }\end{array}$ & \\
\hline 14. & $\begin{array}{lrr}\text { A User-Centric } & \text { WS-Mediator } \\
\text { framework } & \text { foron-the-fly } & \text { Web } \\
\text { Service } & \text { Composition } & \text { Next } \\
\text { Generation } & \text { Network(NGN)Next }\end{array}$ & $\begin{array}{l}\text { User centric } \\
\text { WS-mediator } \\
\text { which allows } \\
\text { the end-user to }\end{array}$ & $\begin{array}{l}\text { Comprehensive } \\
\text { framework for a } \\
\text { user centric WS- } \\
\text { mediator which is }\end{array}$ & $\begin{array}{l}\text { Existing work has } \\
\text { limitation on their } \\
\text { agility to create a } \\
\text { composed service }\end{array}$ \\
\hline
\end{tabular}


www.ijtsrd.com

\begin{tabular}{|c|c|c|c|c|}
\hline & $\begin{array}{l}\text { Generation } \\
\text { Service(NGS)composition engine } \\
\text { which generates an executable } \\
\text { autonomous entity. } \\
\text { Generation Sext- } \\
\text { Networks (NGSON) [24]. }\end{array}$ & $\begin{array}{l}\text { mash up the } \\
\text { service in his } \\
\text { way on the } \\
\text { fly. }\end{array}$ & $\begin{array}{l}\text { capable } r \text { of } \\
\text { dynamic service } \\
\text { composition. }\end{array}$ & $\begin{array}{l}\text { on the fly according } \\
\text { to the } \\
\text { desire/need of an } \\
\text { end-user at a given } \\
\text { time/place. }\end{array}$ \\
\hline 15 & $\begin{array}{l}\text { Computational model of service } \\
\text { quality to calculate the service } \\
\text { parameters of specific quality } \\
\text { topological sorting algorithm [25]. }\end{array}$ & $\begin{array}{l}\text { The } \\
\text { combinatorial } \\
\text { optimization } \\
\text { method for } \\
\text { web services } \\
\text { based on } \\
\text { workflow } \\
\text { model. } \\
\text { Scheduling } \\
\text { algorithm for } \\
\text { service } \\
\text { composition } \\
\text { have been } \\
\text { optimized. }\end{array}$ & $\begin{array}{l}\text { Optimization } \\
\text { program enhances } \\
\text { the web services } \\
\text { quality of service, } \\
\text { optimizes service } \\
\text { scheduling } \\
\text { function, and } \\
\text { shorts the response } \\
\text { time of the } \\
\text { application } \\
\text { services portfolio, } \\
\text { in the case of } \\
\text { large-scale } \\
\text { applications. }\end{array}$ & $\begin{array}{l}\text { Existing workflow- } \\
\text { based web service } \\
\text { composition } \\
\text { programs lack the } \\
\text { flexibility to choose } \\
\text { high-quality } \\
\text { services. } \\
\text { The scheduling } \\
\text { performance } \\
\text { degenerates as the } \\
\text { size increases. }\end{array}$ \\
\hline 16 & $\begin{array}{l}\text { 1. "Local" pattern's discovery that } \\
\text { covers partial results through a } \\
\text { dynamic programming } \\
\text { algorithm. } \\
\text { 2. Composite service (CS) mining } \\
\text { algorithm. } \\
\text { 3. Approach Summarization: } \\
\text { 4. Collecting execution history } \\
\text { 5. Analyzing the execution history } \\
\text { 6. Improving the composition } \\
\text { model } \\
\text { 7. Composite service log: } \\
\text { 8. Collecting Web service logs } \\
\text { 9. Composite Service log structure } \\
\text { 10. Sufficient and minimal number } \\
\text { of CS instances } \\
\text { 11. SDT: Statistics Dependency } \\
\text { Table [28]. }\end{array}$ & $\begin{array}{l}\text { Mining } \\
\text { approach } \\
\text { discovers } \\
\text { more } \\
\text { Complex } \\
\text { features } \\
\text { with a better } \\
\text { specification } \\
\text { of the "fork" } \\
\text { operator and } \\
\text { the "join" } \\
\text { operator. }\end{array}$ & $\begin{array}{l}\text { CS mining } \\
\text { supports } \\
\text { business process } \\
\text { rediscovery based } \\
\text { on a log analysis. } \\
\text { A set of mining } \\
\text { techniques to } \\
\text { discover CS } \\
\text { transactional flow } \\
\text { in order to improve } \\
\text { CS recovery } \\
\text { mechanisms. } \\
\text { Deals better with } \\
\text { concurrency } \\
\text { through the } \\
\text { introduction of the } \\
\text { "concurrent } \\
\text { window" }\end{array}$ & $\begin{array}{l}\text { Previous approaches } \\
\text { may fail to ensure } \\
\text { CS reliable } \\
\text { executions in some } \\
\text { cases, even if they } \\
\text { formally validate the } \\
\text { CS model. }\end{array}$ \\
\hline 17 & $\begin{array}{l}\text { Novel search method for Web } \\
\text { services called WSQBE. } \\
\text { providers may manually assign a } \\
\text { category to their services from a } \\
\text { number of predefined options [29]. }\end{array}$ & $\begin{array}{l}\text { Representing } \\
\text { Web services } \\
\text { and queries } \\
\text { as a collection } \\
\text { of vector } \\
\text { subspaces. }\end{array}$ & $\begin{array}{l}\text { UDDI registries } \\
\text { with search } \\
\text { facilities }\end{array}$ & $\begin{array}{l}\text { UDDI registries- } \\
\text { difficult to use and } \\
\text { often require service } \\
\text { consumers to spend } \\
\text { too much time } \\
\text { manually browsing } \\
\text { and selecting service } \\
\text { descriptions. }\end{array}$ \\
\hline 18 & $\begin{array}{l}\text { Grid technology provides an } \\
\text { information infrastructure. } \\
\text { Semantic Web Services Integration } \\
\text { Life Cycle: }\end{array}$ & $\begin{array}{l}\text { Semantic } \\
\text { based } \\
\text { discovery and } \\
\text { composition }\end{array}$ & $\begin{array}{l}\text { A new and generic } \\
\text { semantic Web } \\
\text { services } \\
\text { integration and }\end{array}$ & $\begin{array}{l}\text { Manual, discovery, } \\
\text { invocation and } \\
\text { composition of Web } \\
\text { services. Significant }\end{array}$ \\
\hline
\end{tabular}


www.ijtsrd.com

\begin{tabular}{|c|c|c|c|c|}
\hline & $\begin{aligned}> & \text { Business Process } \\
& \text { Modelling. } \\
> & \text { Semantics Enrichment of } \\
& \text { Workflow. } \\
> & \text { Runtime Phase. } \\
> & \text { Development. } \\
> & \text { Service Management [32]. }\end{aligned}$ & of SWSs & $\begin{array}{l}\text { composition } \\
\text { lifecycle to } \\
\text { facilitate the } \\
\text { semantic based } \\
\text { integration and } \\
\text { composition of } \\
\text { Grid services. }\end{array}$ & $\begin{array}{l}\text { hamper the } \\
\text { automatic process of } \\
\text { enterprise } \\
\text { application } \\
\text { integration. }\end{array}$ \\
\hline 19 & Ontology based model [33] & $\begin{array}{l}\text { Semantic } \\
\text { model for web } \\
\text { service } \\
\text { discovery and } \\
\text { description. }\end{array}$ & $\begin{array}{l}\text { Similarity } \\
\text { matching of web } \\
\text { services is } \\
\text { implemented } \\
\text { through } \\
\text { summarization of } \\
\text { semantic similarity } \\
\text { value. }\end{array}$ & $\begin{array}{l}\text { Method has poor } \\
\text { precision and recall } \\
\text { for service } \\
\text { discovery. }\end{array}$ \\
\hline 20 & $\begin{array}{l}\text { Engineering approach: } \\
\text { 1) Reflecting the dynamic nature } \\
\text { of environment. } \\
\text { 2) Understanding the types of } \\
\text { requirements. } \\
\text { 3) Linking some of these } \\
\text { requirements to capacity } \\
\text { development [34]. }\end{array}$ & $\begin{array}{l}\text { Capacities } \\
\text { empower Web } \\
\text { service with } \\
\text { additional } \\
\text { 'skills', which } \\
\text { make them } \\
\text { select the } \\
\text { appropriate } \\
\text { actions to } \\
\text { carry out in } \\
\text { response to } \\
\text { specific } \\
\text { environment } \\
\text { requirements. }\end{array}$ & $\begin{array}{l}\text { The first goal } \\
\text { identifies the types } \\
\text { of requirements } \\
\text { The second goal } \\
\text { details the } \\
\text { Capacities } \\
\text { The third goal } \\
\text { reviews the } \\
\text { business logic }\end{array}$ & \\
\hline 21. & $\begin{array}{l}\text { Mathematical programming model: } \\
0 \text {-1 linear program is solved } \\
\text { using a standard solver (CPLEX) } \\
\text { QoS criteria represent the non } \\
\text { functional properties of web } \\
\text { services [36]. }\end{array}$ & $\begin{array}{l}\text { QoS aggregate } \\
\text { measure } \\
\text { and satisfying } \\
\text { transactional } \\
\text { properties. }\end{array}$ & $\begin{array}{l}\text { CPLEX is very } \\
\text { performing } \\
\text { for solving such } \\
\text { very big size } \\
\text { problems } \\
\text { QoS is measured } \\
\text { by a weighted } \\
\text { sum. }\end{array}$ & \\
\hline 22 & $\begin{array}{l}\text { Web service composition using } \\
\text { SHOP2 } \\
\text { architecture:BPEL4WS [37]. }\end{array}$ & $\begin{array}{l}\text { SHOP2 and } \\
\text { BPEL4WS for } \\
\text { web service } \\
\text { composition } \\
\text { to facilitate } \\
\text { context } \\
\text { awareness. }\end{array}$ & $\begin{array}{l}\text { Scenario: mail } \\
\text { replication system- } \\
2 \text { sub processes } \\
\text { 1) Retrieve } \\
\text { mail } \\
\text { 2) Send mail }\end{array}$ & $\begin{array}{l}\text { Often static and } \\
\text { inflexible. } \\
\text { Not suited to } \\
\text { operate in a } \\
\text { pervasive } \\
\text { computing } \\
\text { environment. } \\
\text { The network } \\
\text { bandwidth } \\
\text { and the type of } \\
\text { computing device }\end{array}$ \\
\hline
\end{tabular}


www.ijtsrd.com

\begin{tabular}{|c|c|c|c|c|}
\hline & & & & $\begin{array}{l}\text { affect the mail } \\
\text { retrieval and } \\
\text { sending. }\end{array}$ \\
\hline 23 & $\begin{array}{l}\text { Rigorous framework for the } \\
\text { composition of Web Services } \\
\text { within a higher order logictheorem } \\
\text { prover [39]. }\end{array}$ & $\begin{array}{l}\text { Approach: } \\
\text { proofs-as- } \\
\text { processes } \\
\text { paradigm that } \\
\text { enables } \\
\text { inference rules } \\
\text { of Classical } \\
\text { Linear Logic } \\
\text { (CLL) to be } \\
\text { translated into } \\
\text { p-calculus } \\
\text { processes. }\end{array}$ & $\begin{array}{l}\text { Web Services } \\
\text { compositions } \\
\text { described using } \\
\text { thep-calculus by } \\
\text { performing CLL } \\
\text { proofs. }\end{array}$ & $\begin{array}{l}\text { Interesting } \\
\text { properties such as } \\
\text { liveness, safety, and } \\
\text { deadlock-freedom } \\
\text { have } \\
\text { not been } \\
\text { investigated }\end{array}$ \\
\hline 24 & $\begin{array}{l}\text { Optimization is carried out by ACO } \\
\text { (Ant Colony Optimization) } \\
\text { algorithm.Ranking is done using } \\
\text { performance index which is } \\
\text { calculated dynamically from the } \\
\text { non-functional QoS parameters. } \\
\text { GA approach-finding the optimal } \\
\text { composition [42]. }\end{array}$ & $\begin{array}{l}\text { For a scalable } \\
\text { application, } \\
\text { servicing } \\
\text { increasing } \\
\text { number of } \\
\text { requests is } \\
\text { critical for its } \\
\text { performance. }\end{array}$ & $\begin{array}{l}\text { Both Optimization } \\
\text { and Ranking on } \\
\text { this composite } \\
\text { Web Service } \\
\text { which delivers } \\
\text { high performance. } \\
\text { - Reusability } \\
\text { - Robustness } \\
\text { - Fault tolerance } \\
\text { Optimization and } \\
\text { ranking that } \\
\text { ultimately leads to } \\
\text { the execution of } \\
\text { the best service. }\end{array}$ & $\begin{array}{l}\text { Composite web } \\
\text { service without any } \\
\text { optimization } \\
\text { or Ranking- no } \\
\text { guarantee } \\
\text { that the best } \\
\text { performing web } \\
\text { service is selected. }\end{array}$ \\
\hline 25 & $\begin{array}{l}\text { Graph based approach. DAG to } \\
\text { represent web service composition } \\
\text { [44]. }\end{array}$ & $\begin{array}{l}\text { The } \\
\text { composition } \\
\text { algorithm } \\
\text { is designed to } \\
\text { effectively } \\
\text { exploit the } \\
\text { possibilities of } \\
\text { multiprocessor } \\
\text { platforms. The } \\
\text { framework's } \\
\text { architecture is } \\
\text { adjusted to } \\
\text { parallel } \\
\text { processing } \\
\text { over a single } \\
\text { data structure. }\end{array}$ & $\begin{array}{l}\text { A huge amount of } \\
\text { computation is } \\
\text { performed during } \\
\text { preprocessing. } \\
\text { Supports } \\
\text { multiprocessor } \\
\text { platforms. } \\
\text { Immediate } \\
\text { response to queries }\end{array}$ & $\begin{array}{l}\text { Approach-issues, } \\
\text { - } \text { Find all possible } \\
\text { solutions } \\
\text { - Maximize pre } \\
\text { processing } \\
\text { - Parallel } \\
\text { processing }\end{array}$ \\
\hline
\end{tabular}

\section{B. Evaluation of composition approaches}

An Evaluation of dynamic Web Service Composition Approaches described and are very much important for the measurement of the performance of it [41]. Business-toBusiness Integration (B2Bi)-technology web service composition languages: WS-BPEL 
with WSDL, OWL-S with Golog /Planning. Framework categories:

- Monolithic,

- Staged,

- Template-based service composition and execution.

The following dynamic service composition approaches uses the effective performance evaluation methodologies

- eFlow

- METEOR-S

- WebTransact

- DynamiCoS

- $\mathrm{SeGSeC}$

The trustworthiness of the web services is very much important in defining the QoS and obtaining trustworthiness of SOAs can also be achieved as follows [43]

- $\quad$ self-healing web service compositions

- $\quad$ service and process description,

- monitoring and recovery strategies.

Roadmap for research finalizedto obtaining self-healing service compositions. The three recovery strategies are easier to understand when used to recover from functional errors. In the field of dynamic composition of web services, WSCG(Web Service Composition Graph) proposes a framework that provides visual design, validation and development of compositions using graph theories. Triana as a Graphical Web Services Composition Toolkit [45]. Extend the functionality of the Triana problem-solving environment into the Web services world. Triana uses a peer to peer subset of the GridLab GAT Interface. Web services composition system needs the following mechanisms:
- Service discovery methods

- Service composition methods

- Transparent invocation methods

- Transparent publishing of services outlined

Triana is a framework to integrate graphical creation of Web services workflows within the open source. In particular, Triana handles discovery, invocation, composition, and publishing of Web services through the WServe API. The GAT/GAP are middle ware independent APIs that allows transparent access to various underlying middle ware architectures. By facilitating the transparent construction of Web services workflows, users can create new composite services which offer more functionality thanatomic services; Share and replicate workflows with other users.

\section{CONCLUSION}

This review has an objective to give an overview about the recent trends in the development of various web service composition approaches. Initially we identified the existing approaches used for the composition. These approaches are classified according to the processing of the service descriptions, which can be either syntactic or semantic based service process. The review also comprises the methodologies used for composition and the parameters used for selection and matching processes. Every composition approaches have its own merits and demerits. Most of the syntactic approaches have used QoS parameters for composition and semantic approaches are domain specific and the implementation needs basic knowledge about the domain, semantic description, ontologies and composition engine tasks. 


\section{REFRENCES:}

[1]. Dustdar, S. and Schreiner, W., 2005. A survey on web services composition. International journal of web and grid services, 1(1), pp.1-30.

[2]. Granell, C., Díaz, L. and Gould, M., 2010. Service-oriented applications for environmental models: Reusable geospatial services. Environmental Modelling \& Software, 25(2), pp.182198

[3]. F. Casati, M. Sayal, and M.-C. Shan. Developing e-services for composing eservices, In Proceedings of 13th International Conference on Advanced Information Systems Engineering(CAiSE), Interlaken, Switzerland, June 2001. Springer Verlag.

[4]. Ziyun Deng, Lei Chen, Tingqing He and Tao Meng, A Reliability Calculation Method for Web Service Composition Using Fuzzy Reasoning Colored Petri Nets and Its Application on Supercomputing Cloud Platform"

[5]. George Markou, IoannisRefanidis, Nondeterministic planning methods for automatedweb service composition, Artificial Intelligence Research,Vol. 5, No. 1, 2016

[6]. MarziehKarimi, Faramarz Safi Esfahani and NasimNoorafza, Improving Response Time of Web Service Composition based on QoS Properties,Indian Journal of Science and Technology, Vol 8(16),2015.

[7]. Amina A, Md. Berrada,DrissChenoun, Bochaib B, A semantic web service composition for e-government services, Journal of Theoretical and Applied Information Technology, Vol.71 No.3,2015

[8]. M. Suchithra, and M. Ramakrishnan, A Survey on Different Web Service Discovery Techniques, Indian Journal of Science and Technology, Vol 8(15),2015
[9]. Kirit Modi, Sanjay Garg, "Dynamic Web Services Composition using Optimization Approach", IJCSC, pp.285-293, Vol 6 Number 2,2015.

[10]. Angel Lagares L, florian D, Boualem B, Web Service Composition: A Survey of Techniques and Tools, ACM Comput. Surv. 48, 3, Article 33 ,41 page, 2015.

[11]. Passent El-Kafrawy, EmadElabd, HanaaFathi, A trustworthy Reputation Approach for Web Service Discovery,ScienceDirect, International Conference on Communication, Management and Information Technology,2015.

[12]. Amina Bourouis, Kais Klai, Yamen El Touati, Nejib Ben Hadj-Alouane, Opacity Preserving Abstraction for Web Services and their Composition Using SOGs, IEEE International Conference on Web Services,2015.

[13]. Umar Shehu, Gregory Epiphaniou, Ghazanfar Ali Safdar, A Survey of QoSaware Web Service Composition Techniques,International Journal of Computer Applications (0975 - 8887), Volume 89 - No 12, 2014.

[14]. MojtabaKhezrian, Ali Jahan, Wan Mohd Nasir Wan Kadir, Suhaimi Ibrahim,An Approach for Web Service Selection Based on Confidence Level of Decision Maker", PLoS ONE 9(6): e97831,2014.

[15]. R. Naveen Kumar, Sayyad Rasheeduddin, A Dynamic Privacy Model for Web Service Composition, International Journal of Computer Application and Engineering Technology, Volume 3-Issue 4, Oct 2014. Pp. 262-266,2014.

[16]. Jian $\mathrm{Wu}$, Liang Chen, ZibinZheng,Michael R. Lyu, ZhaohuiWu, Clustering Web services to facilitate service discovery,Springer,KnowlInfSyst (2014) 38:207-229,2014. 
[17]. Le DuyNgan,RajaramanKanagasabai, Semantic Web service discovery: stateof-the-art and research challenges, Springer PersUbiquitComput (2013) 17:1741-1752,2012.

[18]. M. AllamehAmiri, V. Derhami, M. Ghasemzadeh,QOS-Based web service composition based on genetic algorithm, Journal of AI and Data Mining, Vol. 1, No.2,63-73,2013.

[19]. Bixin Li, Shunhui Ji, Dong Qiu, Hareton Leung, and Gongyuan Zhang, Verifying the Concurrent Properties in BPEL Based Web Service Composition Process, IEEE TRANSACTIONS ON NETWORK AND SERVICE MANAGEMENT, VOL. 10, NO. 4, 2013.

[20]. YashpalsinhJadeja, Kirit Modi, and AnkurGoswami,Context Based Dynamic Web Services Composition Approaches: a Comparative Study, International Journal of Information and Education Technology, Vol. 2, No. 2, April 2012.

[21]. N.Sasikaladevi,L.Arockiam, Genetic Approach for Service Selection Problem in Composite Web Service", International Journal of Computer Applications (0975 - 8887), Volume 44No.4, 2012.

[22]. Peter Bartalos, M'ariaBielikov'a, Automatic Dynamic Web Service Composition: A survey and problem Formalization, Computing and Informatics, Vol. 30, 2011, 793$827,2011$.

[23]. CRISTINA BIANCA POP, VIORICA ROZINA CHIFU, IOAN SALOMIE, RAMONA BIANCA BAICO, MIHAELADINSOREANU, GEORGIANA COPIL, AHybrid FireflyInspired Approach for Optimal Semantic Web Service Composition, Scalable Computing: Practice and Experience, Volume 12, Number 3, pp. 363369,2011 .
[24]. Tuo Zhang, Ken Chen, MaamarAkerma, JiWen Yan,A User-Centric WSMediator framework for on-the-fly Web Service Composition, 19th Telecommunications forum TELFOR, 2011.

[25]. Tongtong Zhao, Yanli Feng, Xiangai Liu,An Optimization Method of Workflow-based Web Service Composition Model,IEEE, International Conference of Information Technology, Computer Engineering and Management Sciences, 2011.

[26]. Tuo Zhang, Ken Chen, ChunYang Yin, MaamarAkerma, An experience of a lightweight user-centric dynamic service composition mechanism, IEEE International Conference on High Performance Computing and Communications, 2011.

[27]. Zoltán ĎURČÍK, Translation of Semantic Web Services Descriptions into a Planning Problem, SCYR 2010 10th Scientific Conference of Young Researchers - FEI TU of Košice,2010.

[28]. WalidGaaloul, Karim Baïna, Claude Godart, Log-based mining techniques applied to Web service composition reengineering,Springer, SOCA (2008) 2:93-110.2008.

[29]. Marco Crasso, Alejandro Zunino, Marcelo Campo, Easy web service discovery: A query-by-example approach,Science Direct, Science of Computer Programming 71 (2008) 144164,2008.

[30]. SANDEEP KUMAR, R. B. MISHRA, Cognition based Service Selection in Semantic Web Service Composition,2008.

[31]. Maurice H. terBeek, Antonio Bucchiarone, StefaniaGnesi,Formal Methods for Service Composition, ANNALS OF MATHEMATICS, COMPUTING \& 
TELEINFORMATICS, VOL 1, NO 5, 2007, PP 1-10,2007.

[32]. Muhammad Ahtisham Aslam, Jun Shen, Soren Auer, Michael Herrmann, An integration life cycle for semantic Web services composition, University of Wollongong,2007.

[33]. YANG

xuemei,XULizhen,DONGYisheng,WAN GYongli, Web Service DescriptionAnd Discovery Based On Semantic Model,Wuhan University Journal of Natural Sciences, Vol.11 No.5,2006.

[34]. ZAKARIA MAAMAR, SAMIR TATA, KOKOU YETONGNON,DJAMAL BENSLIMANE and PHILIPPE THIRAN, A goal-based approach to engineering capacity-driven Web services,Cambridge University, The Knowledge Engineering Review, Vol. 29:2, 265-280

[35]. Jinghai Rao and Xiaomeng Su, A Survey of Automated Web Service Composition Methods.

[36]. VirginieGabrel, Maude Manouvrier, ImenMegdiche and C'ecile Murat, A new 0-1 linear program for QoS and transactional-aware web service composition,IEEE,2012.

[37]. Maja Vukovic,Peter Robinson, Adaptive, Planning Based, Web Service CompositionFor Context Awareness.

[38]. P. Traverso and M. Pistore,Automated Composition of Semantic Web Services into Executable Processes, ITC-IRST University of Trento.
[39]. PetrosPapapanagiotou, Jacques D. Fleuriot, A theorem proving framework for the formal verification of Web Services Composition, School of Informatics,University of Edinburgh Informatics Forum.

[40]. BoualemBenatallah, Marlon Dumas, ZakariaMaamar, Definition and Execution of Composite Web Services:The SELF-SERV Project, Bulletin of the IEEE Computer Society Technical Committee on Data Engineering.

[41]. Ravi Khadka1 and BrahmanandaSapkota, An Evaluation of Dynamic Web ServiceComposition Approaches, the work is done in the context of DySCoTec Project.

[42]. Pramodh N, Srinath V, Sri Krishna A, Optimization and Ranking in Web Service Composition using Performance Index, International Journal of Engineering and Technology (IJET).

[43]. Sam Guinea,Self-Healing Web Service Compositions.

[44]. Peter Bartalos and M'ariaBielikov'a, SemanticWeb Service Composition Framework Based on Parallel Processing.

[45]. ShalilMajithia, Ian Taylor, Matthew Shields, Ian Wang, Triana as a Graphical Web Services Composition Toolkit 